\title{
Danish Tax News
}

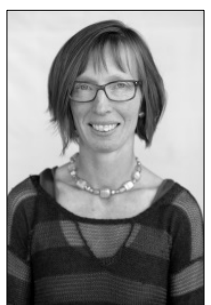

Professor WSR

Inge Langhave Jeppesen

Department of Law

University of Southern Denmark

\section{Introduction}

Morten Østergaard of the Social-Liberal Party (R) was appointed Minister for Taxation from 3 February 2014, replacing Jonas Dahl of the Socialist People's Party (SF).

\section{General and major tax initiatives}

\subsection{Commission on pension savings}

A commission on pension savings in Denmark has been set up. The commission's mandate is primarily to analyse the influence of the current pension system on the incentive to work before and after beginning to receive a pension, incentives for private savings and the allocation of private savings between pension savings and other kinds of saving.

If the commission concludes that the current system leads to inappropriate results, its mandate also includes proposing concrete amendments to the current pension system, including amendments to the tax regime for pension schemes. The commission is led by Professor Torben M. Andersen, and its report is due in the autumn of 2016.

\subsection{Updating the Tax Control Act}

The Tax Control Act dates back to 1946 and it is now time for an updating. The aim is to achieve the right balance between taxpayers' legal rights and the need for efficient up-to-date control of tax returns.

As part of the updating process an updating forum and a panel of experts have been formed. The updating forum includes representa- 
tives from several Danish business organisations. Professor Jan Pedersen, Professor Gorm Toftegaard Nielsen and Margrethe Nørgaard head of the SKAT group on legal rights (of the Danish Customs and Tax Administration) form the panel of experts.

The aim is to propose an amendment to the Tax Control Act by October 2015.

\subsection{Committee on business taxation}

In May 2014 the Danish government launched a 'Package for Growth 2014'. The package includes the formation of a committee on business taxation. The committee will identify potential problems in the current taxation of business income and investment income, as it is thought that the differences in taxation can have an impact on entrepreneurial activity. Therefore the committee will investigate the interaction and the balance between the taxation of business income and the taxation of investment income.

The committee's report to the Danish government is due in 2015.

\section{Package for Growth 2014 (Vækstpakke 2014)}

On 8 May 2014 the Danish government launched its Package for Growth 2014 (Vxkstpakke 2014). This is not to be confused with The Plan for Growth in Denmark which was launched in 2013.

The Package for Growth 2014 includes some tax initiatives which will lead to legislation in the upcoming session of parliament. One initiative is the formation of the committee on business taxation described above. Other initiatives include:

\subsection{Modification of the tax relief for employed researchers}

In future employed researchers can profit from the low researcher tax of $30 \%$ on the gross income when a researcher's monthly salary exceeds approximately DKK 60,600. This is DKK 10,000 below the current level.

\subsection{Tax relief on investments in entrepreneurial activity}

There will be tax relief on income from investments in small unlisted companies. The idea is to make it easier for small companies to attract risk capital. The annual relief will be up to DKK 650,000.

\subsection{Modification of the taxation of dividends from shares}

In 2012 tax exempt portfolio shares were introduced pursuant to Section 4 C of the Taxation of Capital Gains on Sale of Shares Act. Tax exempt portfolio shares can only be held by a legal person as opposed to

\section{Inge Langhave Jeppesen}


natural persons. The shares must be in an unlisted company and the shareholder must hold less than $10 \%$ of the capital. The capital gain on such shares is tax exempt, whereas dividends from such shares are fully taxable.

In order to make it easier for such companies to attract risk capital, the taxation of dividends from tax exempt portfolio shares will be eased. In future only $70 \%$ of the dividend will be taxable. In connection with the ongoing lowering reduction of the corporation tax rate to $22 \%$, the actual taxation of dividends will be $15 \%$ as from 2016 .

\subsection{Full deduction of VAT for nights spent at a hotel}

In 2013 it was decided to increase the deductibility of VAT on business expenses for nights spent at a hotel from $50 \%$ to $75 \%$. As part of the Package for Growth there is a further increase of deductibility to $100 \%$.

\section{Hiring-out of labour}

Law No 921 of 18 September 2012 amended the law on limited tax liability on the hiring-out of labour. The intention was to bring the provision into line with Article 15 of the OECD Model Tax Convention.

Pursuant to Section 2(1)(3) of the Taxation at Source Act, there is hiring-out of labour when the service provided by an individual is an integral part of the business activities of the Danish enterprise to which the services are provided.

The amendment has led to a substantial number of cases being brought before the National Tax Board on the interpretation of when a service constitutes an integral part of the business activities of a Danish enterprise. The National Tax Board's interpretations have resulted in a broad understanding of this question.

The emphasis has been almost entirely on whether the service provided constitutes part of the business activities of the Danish enterprise, without regard to who is responsible for the service provided, i.e. the Danish enterprise or the foreign formal employer.

It has been argued that this interpretation is not in line with Article 8.13 and 8.14 of the commentary on the OECD Model Tax Convention, where other factors are also emphasised, ${ }^{1}$ and that if a service is provided by an individual as part of an employment relationship between the individual and the Danish enterprise, these additional factors must be taken into account.

1 Lars Kjærgaard Terkilsen, “Arbejdsudleje - integreret del af virksomheden og dobbeltbeskatningsoverenskomsterne", SR2013.171 
This has led to the publication of a new guidance note in SKM2014.478.SKAT on the definition of the hiring-out of labour. It spells out that the Danish interpretation is to be understood in accordance with the OECD Model Tax Convention. Thus when deciding whether a service provision qualifies as hiring-out of labour, both the question of whether the service constitutes an integral part of the business activities and the additional factors must be considered.

The guidance note explains in detail the factors that are to be taken into consideration. It also contains several examples of the hiring-out of labour and how they are to be interpreted.

The guidance note came into force on 27 June 2014 and covers all contracts for the hiring-out of labour concluded since 19 September 2012.

\section{Major new tax legislation}

\subsection{Tightening up the taxation of certain dividends.}

Law No 274 of 26 March 2014 introduced some further provisions on the requalification of capital gains on shares as dividends. The Law came into force on 1 February 2014 and is applicable to transfers of shares from 20 November 2013.The main reason for these provisions is that capital gains on portfolio shares in unlisted companies held by companies are tax exempt, whereas dividends from such shares are taxable. This gives rise to tax planning.

Briefly, tax planning profits from the fact that cash payments in connection with share transfers, mergers or corporate divisions are regarded as sales of shares and are to be covered by the Taxation of Capital Gains on Shares Act.

If, in connection with share transfers, mergers or corporate divisions, some of the remuneration is paid in shares and some in cash, the shareholder will still be shareholder but they will also be able to convert a taxable dividend into a tax exempt capital gain on shares. In particular this is possible for companies holding tax exempt portfolio shares in unlisted companies pursuant to Section $4 \mathrm{C}$ of the Taxation of Capital Gains on Shares Act. ${ }^{2}$

To avoid this kind of tax planning amendments have been made to Section 9 of the Tax Treatment of Mergers Act, Section 2 D of the Corporation Tax Act and Section 2(1)(6) of the Tax at Source Act. The idea

2 This can also be the case in some other situations where a dividend is not tax exempt pursuant to either Section 13(1)(2) (where there is full tax liability) or Section 2(1)(c) (where there is limited tax liability) of the Corporation Tax Act. 
is that when there is a share transfer with remuneration consisting of both shares and cash, the cash payment is to be regarded as dividend and is thus to be taxable as a dividend.

In the case of a tax exempt share transfer, merger or corporate division a cash payment is to be regarded as a dividend pursuant to Section 9 of the Tax Treatment of Mergers Act, provided the shareholder still holds shares in the transferring or receiving company or in companies in the same corporate group as the transferring or receiving company.

In the case of a taxable share transfer, merger or corporate division, the qualification of a cash payment is covered by Section $2 \mathrm{D}$ of the Corporation Tax Act, which was introduced in 2012. Under the original provision, for a transfer of shares etc. within a corporate group, ${ }^{3}$ remuneration in cash or payment other than in the form of shares in the receiving company was regarded as a dividend. There is an exemption if a dividend paid by the receiving company to the transferring company is tax exempt pursuant to Section 13(1)(2) of the Corporation Tax Act. This is quite a complex provision and its complexity has been increased by the recent amendments.

Section $2 \mathrm{D}(2)$ of the Corporation Tax Act broadens the scope of the provision, as it also includes remuneration in cash etc. when the share transfer is not within a corporate group. Thus if a share transfer is made between two companies that are not within a group, a cash payment will still be regarded as a dividend and not as a sale of shares. Section $2 \mathrm{D}(4)$ of the Corporation Tax Act broadens the scope further as payment will be qualified as a dividend in the case of mergers and corporate divisions.

With regard to share transfers 4 the broad scope is limited in some ways. A cash payment will only be qualified as a dividend if the remuneration is made partly in cash and only if the receiving company is dormant. If the receiving company is active ${ }^{5}$ or if the full remuneration is made in shares, the provision does not apply.

Also the provision does not apply if the remuneration is made in full other than by shares. It is a condition that the transferring company does not hold shares in the receiving company or companies in the

3 See Section 2 of the Tax Assessment Act on the definition of a corporate group.

4 As a consequence, in mergers or corporate divisions a cash payment will be regarded as a dividend even though the shares are transferred to an active company.

5 See Section $33 \mathrm{~A}(3)$ of the Corporation Tax Act on whether a company is to be regarded as active. Section $2 \mathrm{D}(3)$ elaborates further on when the company is to be regarded as active. 
same corporate group or in the company whose shares are transferred.

As mentioned earlier, the provision in Section $2 \mathrm{D}$ is quite complex and cannot be explained in full here. ${ }^{6}$

The amendment to Section 2(1)(6) of the Taxation at Source Act is equivalent to the amendment to Section $2 \mathrm{D}$ of the Corporation Tax Act. It concerns the requalification of capital gains on shares as dividends for natural persons subject to limited tax liability on dividends from Danish companies.

\subsection{Postponement of payment of exit-tax for companies}

On 18 July 2013 in Case C-261/11 Commission v Denmark the Court of Justice of the European Union (CJEU) ruled on the Danish exit taxation on companies transferring assets and liabilities from Denmark to another Member State. Under the Danish provisions the exit tax was due at the time of transfer, and no credit was granted. The CJEU ruled that this breached Article 49 of the Treaty on the Functioning of the European Union.

Law No 170 of 26 February 2014 amended the Corporation Tax Act to bring exit taxation into line with Union law. Pursuant to Section 26 of the Corporation Tax Act it is now possible to postpone payment of exit tax when assets and liabilities are transferred within EU/EEA. It is for the company to decide whether to profit from the postponement. If so it must be declared together with the tax return.

If a company decides to postpone payment this must be recorded in a special postponement account pursuant to Section 27 of the Corporation Tax Act. The regulation of the account is set out in detail in Section 27. The amount of the repayment depends on the future annual income and capital gain which would have accrued from the transferred assets if they had still been taxable in Denmark. Tax is calculated on basis of this income which determines the amount of the repayment. As the amortisation period is no longer than 7 years, a minimum repayment of $1 / 7$ th of the account will be made every year.

For details on how the repayment is calculated see Section 27 of the Corporation Tax Act. The amendment came into force on 1 March 2014 and it applies to transfers made in tax year 2013. If a company was subject to exit taxation during 2008-2012, subject to certain conditions it can apply for a postponement of payment in accordance with the new rules.

6 See the travaux préparatoires to L 180, 2013/14; and Jens Wittendorf, “SEL § 2 D mv. - begrænset skattepligt af udbytter", TfS 2014, 283. 


\section{Danish case law}

\subsection{SKM2014.87.HR - On the inclusion of the costs of advisers when calculating the capital gains on loans}

In recent years one of the much debated questions in Danish tax law has been the deductibility of costs related to the acquisition of shares, real property etc. Such costs are generally not deductible pursuant to Section 6(a) of the State Tax Act. But in some cases they can be deductible pursuant to the former Section $8 \mathrm{~J}$ of the Tax Assessment Act or as costs related to the purchase of the asset or liability, i.e. as part of the acquisition cost that is included in the calculation of the capital gain. The Supreme Court has emphasised that, for a cost to be included as an acquisition cost, it must be related to the settlement and completion of the purchase of an asset or liability. ${ }^{7}$

In SKM2014.87.HR a private equity fund had acquired a Danish pharmaceutical company. The acquisition required financing of NOK 4,405 million, of which NOK 3,504 million was loan financed. The lending bank had required all the relevant costs of its advisers to be paid by the borrower. The borrower had also paid the costs for its own advisers. The costs related to arranging securities for the loans, providing the necessary documentation and establishing a group structure to satisfy the lending bank.

When the case came before the Eastern High Court ${ }^{8}$ it ruled that costs paid for the advisers of the lending bank were to be regarded as costs related to obtaining the loan, and they were thus deductible when calculating the capital gain or loss on the debt pursuant to the former Section 26(4) (now Section 26(3)) of the Capital Gains on Securities Act.

Unlike the costs of the advisers of the lending bank, the Eastern High Court held that payments to the borrower's advisers were not regarded as related to obtaining the loan. This question was decided by the Supreme Court in SKM2014.87.HR.

The Supreme Court ruled that costs of advisers can be part of the costs of obtaining a loan. However, the costs must be related to advice on the agreement on the loan. Depending on the size and character of the loan, the advice can include negotiations on the agreement, legal opinions and the provision of security, but it does not include payment to advisers in connection with the general structure and planning of the financing. The Supreme Court also emphasised that it is for the taxpayer to prove into which of these categories a cost falls.

$7 \quad$ See SKM2007.773.HR and SKM2007.775.HR which are the two major decisions on this question.

8 The ruling is published as SKM2011.545.ØLR. 
The Supreme Court found that the costs paid to the borrower's advisers were related to the general structure and planning of the financing and thus not to be included in the acquisition costs and subsequently included in calculating a capital gain. They were sunk costs.

The conclusion is that costs paid to advisers in relation to obtaining debt financing can be part of the acquisition cost of a loan if they are directly related to the financing agreement and obtaining the loan. Depending on the size and the character of the loan these can include a quite broad range of costs paid to advisers. However, this does not include costs related to the more general structuring and planning of the financing.

As such costs can be quite substantial it is very important for taxpayers to be aware of this and to be able to prove that costs are directly related to obtaining a loan as it is for them to satisfy the burden of proof.

\subsection{SKM2014.422.HR - on the deductibility of a constructive loss on the selling of shares}

In SKM2014.422.HR the Supreme Court made an interesting ruling on the deductibility of a loss realised on the selling of shares. The ruling is based on the former Taxation of Capital Gains on Sale of Shares Act, which allowed companies to carry forward a realised loss on the sale of shares if the shares were held for less than three years. The loss could be offset against realised gains on shares held for less than three years.

Despite the case concerns former legislation, it is quite interesting as it deals with whether a fully legal transaction in civil law is to be accepted in a tax law context.

The case concerned a holding company S1 A/S and its subsidiary S2 ApS, as well as subsidiaries of S1 A/S - A A/S and C A/S - and subsidiaries of S2 ApS - B ApS and D ApS. All these companies were part of consolidated group and thus a joint taxation pursuant to Section 31 of the Corporation Tax Act.

A A/S and B ApS had entered into a forward foreign exchange contract for USD/EURO, and C A/S and D ApS had entered into a forward contract for USD/DKK. S1 and S2 had signed a statement of support with the bank, promising to pay the subsidiaries the cash necessary to be able to pay the bank. Upon termination of the forward contracts A and B realised losses on the USD/EURO contract whereas $\mathrm{C}$ and $\mathrm{D}$ realised gains on the USD/DKK contract which were almost equal to the value of the losses of $A$ and $B$.

In accordance with the statement of support, S1 and S2 transferred money to the bank and the amounts were registered as receivables from A and B respectively. A capital increase was then made in A and 
B, and S1 and S2 subscribed for the shares. The capital increase was used to repay the receivables. Subsequently S1 and S2 sold their shares in A and B to another company within the group, thereby realising losses. The amount of these losses was influenced by the capital increases, as they were regarded as the acquisition costs of the shares. These losses could be offset against capital gains on shares.

The Legal Adviser to the Danish Government argued that the companies within a closed system had created losses on the shares, and that the losses should be reduced because the latest capital increases formed part of this closed system with the sole purpose of creating these losses.

The Supreme Court ruled that the forward contracts were almost without economic risk and without any commercial basis. At a group level the forward contracts were financially neutral. Given the effect of the joint taxation, the only purpose of the arrangement was to construct a loss on the shares for S1 and S2. The Supreme Court ruled that part of the losses were not real and that they should therefore be reduced by the amount of the capital increases caused by the loss on the forward contracts. Thus the capital increases were not accepted in a tax law context, even though they had unquestionably taken place according to company law.

The case is interesting because the ruling is an example of the Supreme Court emphasising substance rather than form, disregarding the capital increase as a part of the acquisition cost.

\subsection{SKM2014.14.SR, SKM2014.15.SR, SKM2014.16.SR and SKM2014.294.SR - Shareholder loans and Section $16 \mathrm{E}$ of the Tax Assessment Act.}

Section 16 E of the Tax Assessment Act was adopted in 2012. It states that if a natural person with decisive influence on a company is granted a loan by the company, in most cases it is to be requalified as either a dividend or salary.

There is an exception if the loan is granted as part of a usual business transaction. The meaning of a "normal business transaction" is important. At the beginning of 2014 the National Tax Board published some decisions on this question. SKM2014.14.SR concerned a company which granted loans to limited partnerships which were partly owned by the shareholder of the company. The company served as a holding company in an organisation in which several limited partnerships were "subsidiaries". In other words the company acted as a financing company within a group. As limited partnerships are transparent in Danish tax law, the loans were regarded as having been made to natural persons. The National Tax Board decided that the loans were not to be regarded as part of normal business transaction, 
as they were "proper" loans and not connected to another transaction, such as selling of goods on credit.

SKM2014.294.SR concerned a loan granted by a company to its shareholder. The balance of the company's assets consisted of bonds etc. and other receivables from loans granted. The company argued that its business was partly to grant loans, but the National Tax Board decided that the loan did not form part of a normal business transaction because it was a "proper" loan and only banks provide proper loans as part of their normal business transactions.

To conclude, the term "normal business transaction" is to be interpreted narrowly. If a loan is granted as a "proper" loan it will be deemed a dividend or as salary. It remains to be seen when a loan is to be regarded as part of a usual business transaction. 